\title{
KONSEPTUALISASI HAK DAN KEWAJIBAN WARGA NEGARA DALAM UPAYA BELA NEGARA
}

\author{
Danang Prasetyo ${ }^{1}$, Toba Sastrawan Manik $^{2}$, Dwi Riyanti ${ }^{3}$ \\ 1'danangprasetyo@stipram.ac.id, 2tobasastrawanmanik@gmail.com,3dwiriyanti.ysu@gmail.com, \\ ${ }^{1}$ MKWU PPKn, Sekolah Tinggi Pariwisata Ambarrukmo Yogyakarta \\ ${ }^{2}$ Magister PPKn, Universitas Negeri Yogyakarta \\ 3MKU, Universitas Terbuka
}

\begin{abstract}
ABSTRAK
Upaya bela negara merupakan wujud pertahanan yang harus disesuaikan dengan keadaan masa sekarang dan masa yang akan datang. Bela Negara yang sesuai untuk saat ini ialah bela Negara secara non-fisik, dengan kesadaran dan kenyataan tersebut, konsep dan praktik bela negara merupakan suatu keharusan demi keberlangsungan negara Indonesia mempertahankan kemerdekaan. Tulisan ini merupakan penelitian penelitian kualitatif dengan metode kajain pustaka, data kemudian dianalisis dan dikaji secara induktif. Simpulan dari tulisan ini menegaskan bahwa bela negara merupakan sikap dan perbuatan yang ditunjukkan warga negara, kelompok, dan bangsa dalam mengupayakan yang terbaik untuk kepentingan nasional yang dijiwai oleh kecintaannya kepada Negara Kesatuan Republik Indonesia yang berdasarkan Pancasila dan Undang-Undang Dasar 1945. Konsep bela negara muncul sebagai perwujudan dari patriotimse atau nasionalisme yang harus dimiliki setiap warga Negara. Oleh karena itu, bela negara bersifat hak sekaligus kewajiban lebih didasari rasionalisasi, urgensinya, dan kompleksitas bentuk-bentuk bela negara. Penempatan bela negara sebagai hak dan kewajiban sudah sangat tepat dan kuat, sehingga bela negara tidak selalu mengandaikan, mensyaratkan atau mengkondisikan pihak lain karena bersifat kewajiban. Setiap warga negara berkewajiban untuk membela negara kapan pun dan dalam bentuk apa pun.
\end{abstract}

Kata Kunci: hak warga negara, kewajiban warga negara, bela negara.

\begin{abstract}
Efforts to defend the state are a form of defense that must be adjusted to the present and future conditions. State Defense which is suitable for now is defending the State non-physically, with this awareness and supervision, the concept and practice of defending the state is a must for the sustainability of the Indonesian state of independence. This paper is a qualitative research using literature review method, the data is then analyzed and studied inductively. The conclusion of this paper states that state defense is the attitude and statement shown by citizens, groups and the nation in striving for the best for the national interest which is imbued with their love for the Unitary State of the Republic of Indonesia based on Pancasila and the 1945 Constitution. The concept of state defense appears as the embodiment of patriotim or nationalism that every citizen must have. Therefore, state defense is both a right and an obligation based on the rationalization, urgency and complexity of the forms of state defense. The placement of state defense as rights and obligations is very precise and strong, so that defending the state does not always presume, require or condition other parties because it is an obligation. Every citizen has the obligation to declare the state at any time and in whatever form.
\end{abstract}

Keywors: citizen rights, citizen obligations, state defense. 


\section{PENDAHULUAN}

Hatta pernah berkata, "Hanya ada satu yang pantas menjadi tanah airku yaitu Indonesia. Ia bangkit dan maju karena usaha. Usaha itu adalah aku." John F. Kennedy pernah mengatakan makna yang sama yaitu "Jangan tanyakan apa negara berikan padamu, tapi tanyakan apa yang kamu berikan pada negara."

Dua pendapat tokoh tersebut menekankan hal yang sama yaitu pentingnya sikap dan perbuatan warga negaranya yang bersifat konstruktif dan positif terhadap negara sebagai wujud kecintaan. Sikap dan perbuatan tersebut yang disebut dengan bela negara.

Setiap orang yang hidup di dalam suatu wilayah negara harus memiliki sikap nasionalisme, patriotisme dan bela negara. Siapa pun yang hidup di Indonesia secara moral harus membela tanah air sebagai wujud syukur, rasa terima kasih atas kekayaan dan kenikmatan yang diperoleh dari bumi pertiwi nusantara.

Kajian tentang bela negara selalu menghadirkan tantangan tersendiri. Seiring dengan perubahan zaman, manifestasi bela negara senantiasa terbuka, berubah, dan mengikuti perkembangan. Jika zaman masa kolonial, perang dunia, atau penjajahan, bela negara lebih dituntut kemauan dan keikutsertaan dalam berperang, mengangkat senjata untuk melawan yang disebut dengan musuh yang jelas di depan mata.

Masa sekarang, terlepas apa pun terminologi yang digunakan, bela negara mengalami tuntutan jaman baik dari segi defenisi maupun praksis. Mahfud MD mengatakan bahwa bela negara wujud pertahanan yang harus disesuaikan dengan keadaan sekarang dan masa yang akan datang (Sholikah, 2020). Manifestasi Bela negara saat ini lebih luas dan sangat beragam. Bela negara tidak hanya dipahami sebagai aktivitas atau keikutsertaan di medan perang. Persaingan jaman, kemajuan teknologi, dan budaya menuntut bentuk bela negara yang lain. Berperang tidak lagi bentuk perjuangan yang harus dilakukan di medan perang melainkan di dunia maya, psywar. Terlebih letak geografis Indonesia yang sangat strategis, pengaruh dan intervensi dari negara lain tidak dapat dihindarkan.

Pendapat yang senada ditegaskan oleh Soepandji dan Farid. Menurut keduanya, Indonesia yang secara geopolitik sangat strategis, maka sepanjang Indonesia masih ada maka tidak akan pernah lepas dari global extraordinary networks (Soepandji \& Farid, 2018). Hal ini disebabkan terkoneksinya Indonesia dengan negara lain seiring dengan kemajuan teknologi, juga disebabkan posisi strategis Indonesia yakni diantara dua Benua Asia dan Australia, selain itu juga diantara dua samudera yakni Pasifik dan Hindia.

Berdasarkan pemahaman akankenyataan tersebut, konsep dan praktik bela negara merupakan suatu keharusan demi keberlangsungan dan eksistensi negara Indonesia. Kesadaran historis bahwa Indonesia pernah merasakan pahitnya penjajahan dan eksploitasi besar-besar atas kekayaan bumi pertiwi, semakin menuntut pentingnya mempertahankan kemerdekaan dan sikap membela negara dari segala keinginan yang ingin merampas atau merugikan Indonesia. Afirmasinya adalah upaya bela negara dengan upaya pertahanan, keamanan, dan kemajuan negara.

Berdasarkan Undang Undang Dasar Negara Republik Indonesia (UUD NRI) Tahun 1945, secara eksplit mengatakan bahwa bela negara merupakan hak sekaligus kewajiban bagi warga negara. Hal tersebut disebutkan dalam pasal 27 ayat (3) bahwa setiap warga negara berhak dan wajib ikut serta dalam upaya pembelaan negara. Kemudian pasal 30 ayat (1) bahwa tiap-tiap warga Negara berhak dan wajib ikut serta dalam usaha pertahanan dan keamanan 
negara. Selain dasar tersebut, bela negara dikuatkan dalam Undang-Undang No.3/2002 tentang Pertahanan Negara pada pasal 9 kembali ditegaskan bahwa setiap warga negara berhak dan wajib ikut serta dalam upaya bela negara yang diwujudkan dalam penyelenggaraan pertahanan negara.

Jika membaca isi pasal tersebut, secara jelas tertulis bahwa bela negara merupakan hak dan kewajiban. Hal ini terkesan menimbulkan keambiguan jika hanya memaknai secara sepintas. Timbul pertanyaan, apakah bela negara merupakan hak atau kewajiban? Pertanyaan ini logis mengingat dalam paradigma umum hak dan kewajiban diandaikan secara bersebrangan meski dalam satu kesatuan yang melekat.

Apabila mengacu pandangan umum bahwa hak adalah sesuatu yang harus didapatkan. Hal ini berarti harus ada pihak lain yang harus memenuhi atau memberikan. Hal ini yang disebut dengan kewajiban. Jika bela negara adalah hak sekaligus kewajiban semua warga negara, bagaimana implementasinya? Mana yang terlebih dahulu dilakukan dari sisi hak (menerima) atau dari sisi kewajiban (melakukan atau memberikan)?

Diskusi inilah yang menurut penulis perlu dikaji secara lebih mendalam. Pertanyaan lain juga yang lebih menarik adalah mengapa bela negara disebut sebagai hak dan kewajiban sebagai satu kesatuan sekaligus? Berdasarkan hal inilah, peneliti berusaha mengulas melalui artikel ini yang berusaha mencoba untuk menjawab dan menguraikan hal tersebut secara konseptual.

\section{METODE}

Metode yang digunakan dalam penelitian ini adalah penelitian kualitatif dengan metode kajain pustaka (library research). Penulis menggunakan data-data teoritis atau konseptual dari berbagai sumber seperti buku, jurnal, media massa online maupun offline, majalah, koran, berita media massa, dan lainnya yang mendukung penelitian ini. Data-data tersebut kemudian dianalisis dan dikaji secara induktif dan disajikan secara deskriptif.

\section{HASIL DAN PEMBAHASAN}

Setelah peneliti mendapatkan sumber data dan kemudian dianalisis, didapatkan hasil penelitian sebagai berikut ini.

\section{Konsep Hak dan Kewajiban}

Hak dan kewajiban ialah istilah yang sangat familiar didengar, namun sebenarnya konsep dan pemahaman hak dan kewajiban tidaklah sederhana. Dalam konteks modern, definisi hak sangat panjang dan debatable (Sastry, 2011). Kajian dan pemahaman mendalam tentang hak dan kewajiban justru menyadarkan bahwa hak dan kewajiban sebenarnya tidak terpisah dan bukan berada dalam posisi yang bersebrangan. Sekalipun, anggapan tersebut dalam keadaan tertentu dapat dibenarkan.

Dalam konteks HAM (Hak Asasi Manusia) sebenarnya sebagaimana pandangan awal bahwa hak adalah sesuatu yang didapatkan, jika semua manusia berhak atas asasinya, siapa yang memenuhi hak tersebut? Siapa yang memiliki kewajiban asasi manusia?

Dalam keadaan tertentu secara khususnya dalam konteks kenegaraan, dapat saja dikatakan bahwa negara yang menjamin, memenuhi, melindungi, dan menghormati hak asasi manusia. Dalam hal ini negara dalam posisi berkewajiban (memperlakukan)sedangkan warga negara dalam posisi mendapatkan (diperlakukan).

Menurut Sastry, hak secara teminologi berasal dari Inggris kuno yakni reht atau right (Sastry, 2011). Begitu juga hak dan kewajiban dalam konteks warga negara. Hak adalah kewenangan warga negara untuk melakukan sesuatu sedangkan kewajiban adalah suatu keharusan atau kewajiban yang tidak bisa ditinggalkan oleh warga negara (Yasin, 2009). Hal ini 
akanmelahirkan konsekuensi-konsekuensi pada orang lain. Jika hak ada warga negara, maka negara memiliki kewajiban demikian juga sebaliknya.

Oleh karena itu, hak tidak dapat berdiri sendiri. Hak melibatkan pihak lain yang pada saat yang sama disebut memiliki kewajiban. Hal senada ditegaskan oleh Burgess \& Jackson, (1987) bahwa setiap hak berkorelasi dengan kewajiban begitu pun sebaliknya. Oleh karena itu, hak merupakan kombinasi antara tunutan dan kewajiban (Sastry, 2011).

Menurut Sastry (2011) setidaknya ada 5 elemen hak yaitu: (1) pemegang hak; (2) substansi/isi hak; (3) pihak yang menuntut atau menikmati hak; (4) berhadapan dengan orang atau kelompok lain (yang memiliki kewajiban); dan (5) pembenaran atau legalitas hak.

Menurut Long (1993) setiap hak paling tidak tidak diikuti oleh tiga komponen sekalipun tidak menutup kemungkinan ada komponen lain. Komponen setiap hak menurutnyayaitu: (1) nilai moral atau paling tidak nilai/moral yang membenarkan hak seseorang; (2) kewajiban bagi orang lain untuk membiarkan/membantu memiliki atau melakukan apa yang menjadi haknya; dan (3) legitimasi yang membiarkan/membantu orang memiliki apa yang menjadi haknya.

Kewajiban adalah sisi lain yang tidak dapat dilepaskan. Hampir setiap pembahasan tentang hak selalu mensyaratkan konsep kewajiban. Sekalipun harus diakui bahwa hak lebih populer ketimbang kewajiban. Misal, konsep hak asasi manusia lebih menggema dibandingkan kewajiban asasi manusia.

Apabila merujuk pada istilah asing, kewajiban sering diartikan dari duty dan obligation. Sekalipun lebih sering dianggap bermakna sama, Sastry dengan mengutip pendapat dari Harta antara duty dan obligation berbeda dalam penggunaan waktu. Artinya, tidak selalu hak dikaitkan dengan obligation berbeda dengan duty. Berdasarkan konsep hukum, sekalipun maknanya sama namun memiliki posisi yang berbeda (Sastry, 2011).

Kewajiban dapat diartikan sebagai suatu keharusan yang tidak boleh ditinggalkan oleh warga negara. Kewajiban suatu tindakan atau sikap yang harus diambil atau dilakukan oleh seseorang sesuai dengan kemampuannya (Yasin, 2009). Dengan kata lain, kewajiban adalah sesuatu yang harus dilakukan. Jika tidak ada keharusan, maka sesuatu yang dilakukan tersebut belum bisa dikatakan kewajiban. Oleh karena itu, sama dengan hak yang dijelaskan sebelumnya, kewajiban juga harus memiliki legitimasi moral atau legal. Dengan demikian orang tidak melakukan kewajiban akan menerima sanksi dan hukuman.

Kewajiban (duty) dalam konsep hukum ada dari norma atau telah disyaratkan oleh hukum. Seseorang dianggap benar atau salah apabila telah melakukan atau berbuat sesuai dengan kewajibannya. Jika sesuai dengan kewajiban mereka benar, demikian juga sebaliknya (Sastry, 2011). Oleh karena itu, kewajiban-kewajiban setiap individu harus jelas dan tidak menimbulkan keambiguan.

\section{Hak dan Kewajiban Bela Negara}

Konsep hak dan kewajiban telah diuraikan secara singkat dan jelas pada paparan sebelumnya. Apabila merunut paparan sebelumnya, menimbulkan pertanyaan apakah warga negara dapat memiliki hak dan kewajiban pada saat yang sama pada bidang bela negara? Sebagai jawaban dari pertanyaan tersebut penulis uraikan terlebih dahulu konsep bela negara.

Bela negara adalah sikap dan perbuatan yang ditunjukkan individu, kelompok, dan bangsa dalam mengupayakan yang terbaik terhadap kepentingan nasional. Secara lebih luas bela negara adalah tekad, 
sikap, dan perilaku warga negara yang dijiwai oleh kecintaannya kepada NKRI (Negara Kesatuan Republik Indonesia) yang berdasarkan Pancasila dan Undang-Undang Dasar 1945 yang kemudian rela berkorban demi menjamin kelangsungan hidup bernegara (Umra, 2019). Secara lebih singkat bela negara juga dapat dipahami sebagai membela kepentingan nasional dalam segala aspek berbangsa dan bernegara (Budiwibowo, 1988). Bela negara dalam taraf minimum dan yang paling sederhana adalah bertujuan untuk mempertahankan kepentingan negara.

Bela negara harus disesuaikan dengan kebutuhan zaman. Pada abad ke 18 sampai 19, bela negara lebih cenderung dengan kesediaan untuk berperang dengan mengangkat senjata. Pada era modern, abad21 (yang bukan lagi zaman peperangan), konsep dan praksis bela negara berubah drastis. Era saat ini lebih pada pertarungan atau peperangan non-militer seperti pertarungan politik, teknologi, ekonomi, ideologi, imperalisme budaya, dan lainnya (Subagyo, 2019).

Konsep bela negara muncul sebagai perwujudan dari patriotimse atau nasionalisme yang harus dimiliki setiap warga negara. Iqbal (2017) dalam tulisannya yang dimuat di Majalah Catra mengatakan bahwa bela negara adalah suatu konsep yang disusun oleh perangkat regulasi suatu negara tentang patriotism seseorang, suatu kelompok, atau seluruh komponen dari suatu negara dalam kepentingan mempertahankan eksistensi negara itu sendiri. Patriotisme sendiri lebih merujuk pada sikap cinta tanah air. Patriotisme berasal dari kata patria yang artinya tanah air (homeland) (Primoratz \& Pavkovic, 2007; Sardoc, 2020). Sehingga sikap bela negara setidaknya dilandasi oleh rasa cinta tanah air, kesadaran berbangsa dan bernegara, yakin akan Pancasila dan ideologi bangsa, rela berkorban untuk bangsa dan negara, dan memiliki kemampuan awal bela negara (Rahayu et al., 2019).

Hal ini ditegaskan dalam UndangUndang No.3/2002 tentang Pertahanan Negara Pasal 9 disebutkan bahwa (1) setiap warga negara berhak dan wajib ikut serta dalam upaya bela negara yang diwujudkan dalam penyelenggaraan pertahanan negara. Adapun bentuk-bentuk bela negara disebut dalam ayat (2) dalam pasal yang sama yakni (2) keikutsertaan warga negara dalam upaya bela negara, sebagaimana dimaksud dalam ayat (1), diselenggarakan melalui: pendidikan kewarganegaraan, pelatihan dasar kemiliteran secara wajib, pengabdian sebagai prajurit Tentara Nasional Indonesia secara sukarela atau secara wajib, dan pengabdian sesuai dengan profesi.

Direktorat Jenderal Potensi

Pertahanan Kementerian Pertahanan RI (Ditjen Pothan Kemhan RI) mengatakan setidak ada dua 2 spektrum bela negara yakni secara lunak (soft) dan keras (hard) yang tentunya memiliki perbedaan tersendiri manifestasi bela negara (Supandji, 2012). Secara lebih lengkap ditampilkan dalam tabel di bawah ini.

Tabel 1. Spektrum Bela Negara

\section{SPEKTRUM BELA NEGARA}

\begin{tabular}{c|c}
\hline LUNAK $($ SOFT) & KERAS $($ HARD) \\
\hline Psikologis: & Ancaman Militer:
\end{tabular}

1. Memahami ideologi Pancasila serta UUD NRI 1945

2. Nilai-nilai luhur bangsa Indonesia

3. Wawasan kebangsaan

1. Komponen utama

2. Komponen cadangan

3. Komponen pendukung

4. Rasa persatuan dan kesatuan bangsa dalam kehidupan seharihari

5. Kesadaran bela negara

\section{Fisik:}

1. Pelaksanaan tugas sehari-hari dalam rangka mengisi kemerdekaan 
2. Pengabdian sesuai profesi

3. Menjunjung tinggi nama Indonesia di dunia Internasional (kesenian, olah raga, penelitian, dsb)

4. Penanganan bencana dan ancaman non-militer lainnya (meluasnya narkoba, hoax, perang dagang, dsb)

Sumber: Supandji (2012)

Dari berbagai defenisi tersebut dapat dipahami bahwa bela negara menjadi kewajiban setiap warga negara. Siapa pun yang mencintai NKRI, seyogyanya mempertahankannya sesuai dengan kapasitas dan kemampuannya. Oleh karena itu, menurut hemat penulis bela negara lebih cenderung pada kewajiban. Namun, pencantuman dalam UUD NRI Tahun 1945 dan UU No.3/2002 tentang Pertahanan bahwa bela negara dan adalah hak dan kewajiban menimbulkan dampak atau akibat secara hukum.

Namun penegasan bahwa bela negara sebagai hak adalah afirmasi bahwa negara di sisi lain berkewajiban menyediakan ruang, kesempatan, regulasi, dan perlindungan terhadap bela negara. Hal ini bisa dilihat dalam bentuk bela negara yang disebutkan dalam UU No.3/2002 tentang Pertahanan Negara seperti (a) pendidikan kewarganegaraan; (b) pelatihan dasar kemiliteran secara wajib; (c) pengabdian sebagai prajurit Tentara Nasional Indonesia secara sukarela atau secara wajib; dan (d) pengabdian sesuai dengan profesi.

Contoh-contoh di atas lebih pada hak warga negara. Sehingga dampak hukumnya adalah negara menyediakan dan memfasilitasi pendidikan, memberikan pelatihan militer, membuka kesempatan menjadi TNI. Sedangkan contoh ke empat lebih pada kewajiban sesuai dengan profesi.
Jika merujuk pada 2 spektrum di atas, seluruh warga negara Indonesia dalam tataran lunak (soft) bela negara lebih pada kewajiban sedangkan pada spectrum keras (hard) lebih condong pada hak warga negara yang untuk mendapatkannya harus menunggu kewajiban-kewajiban lain dari pemerintah.

Oleh karena itu, Bela negara bersifat hak sekaligus kewajiban lebih didasari rasionalisasi, urgensi dan kompleksitas bentuk-bentuk bela negara. Sehingga bela negara tidak bisa dikotomikan apakah sebagai hak atau kewajiban. Oleh karena itu, Penempatan bela negara sebagai hak dan kewajiban sudah sangat tepat dan kuat. Dengan demikian bela negara tidak selalu mengandaikan, mensyaratkan atau mengkondisikan pihak lain karena bersifat kewajiban. Setiap orang berkewajiban untuk membela negara kapan pun dan dalam bentuk apa pun. Warga negara juga berhak membela negara sehingga pemerintah harus menyedikaan dan memfasilitasi hak-hak warga negara tersebut.

\section{SIMPULAN}

Penegasan isi dalam pasal UUD NRI tahun 1945 bahwa bela negara merupakan hak dan kewajiban yang harus dimaknai sebagai sesuatu yang sangat fundamental, urgen, dan penting dalam kehidupan negara. Bentuk bela negara juga sangat luas dan kompleks sehingga siapa pun dan kapan pun semua warga negara harus melakukannya. Bela negara dalam konteks hak lebih terbatas dan dalam keadaan tertentu yakni dalam pendidikan dan militer. Oleh karena itu, Apakah hak atau kewajiban, bela negara lebih cenderung dan kuat pada dimensi kewajiban warga negara sekalipun dari sisi hak juga tidak dapat dikurangi. 


\section{DAFTAR PUSTAKA}

Budiwibowo, S. (1988). Revitalisasi pancasila dan bela negara dalam menghadapi tantangan global melalui pembelajaran berbasis multikultural. Citizenship: Jurnal Pancasila Dan Kewarganegaraan, 4(3), 565-585.

Burgess-jackson, K. (1987). Duties, Rights, and Charity. Journal of Social Philosophy, XVIII(3).

Iqbal, M. (2017). Bela Negara Dari Siapa dan Untuk Siapa? Majalah Catra, 913.

Long, R. T. (1993). Abortion, abandonment, and positive rights: The limits of compulsory altruism. Social Philosophy and Policy, 10(1), 166-191. https://doi.org/10.1017/S026505250000 4064

Mitja Sar (Ed.). (2020). Handbook of Patriotism. Springer.

Primoratz, I., \& Pavkovic, A. (Eds.). (2007). Patriotism: Philosophical and Political Perspectives. Ashgate.

Rahayu, M., Farida, R., Negara, P., \& Masalah, R. (2019). Kesadaran bela negara pada mahasiswa. 16(2), 175180.

Sastry, T. S. N. (2011). Introduction to human rights and duties: Vol. First edit
(Issue Human Rights). University of Pune Press.

Sholikah, B. (2020). Mahfud MD. Republika.Co.Id.

https://republika.co.id/berita/qgo451428 /mahfud-md-bela-negara-bukan-hanyahak-tapi-kewajiban

Soepandji, K. W., \& Farid, M. (2018).

Konsep bela negara dalam perspektif ketahanan nasional. Jurnal Hukum Dan Pembangunan, 48(3), 436-456.

Subagyo, A. (2019). Rencana Aksi Nasional Bela Negara: Perspektif Pemerintah Daerah. Jurnal Academia Praja, 2(1), $1-16$.

Supandji, B. S. (2012). Bangga Indonesia: Menjadi Komponen Cadangan Tanah Air. Grasindo.

Umra, S. I. (2019). Penerapan Konsep Bela Negara , Nasionalisme Atau Militerisasi Warga Negara. Lex Renaisance, 4(1), 164-178.

Yasin, J. (2009). Hak Azasi Manusia Dan Hak Serta Kewajiban Warga Negara Dalam Hukum Positif Indonesia. In Syiar Hukum (Vol. 11, Issue 2). https://media.neliti.com/media/publicati ons/25229-ID-hak-azasi-manusia-danhak-serta-kewajiban-warga-negaradalam-hukum-positif-indon.pdf. 